\title{
EFFECT OF GLYCEROL SUPPLEMENTED DIET AT DIFFERENT AGES ON JAPANESE QUAILS ON CECAL MICROFLORA
}

\author{
Onder A. Ustundag ${ }^{1}$, Ahmet E. Tuzun ${ }^{2}$, Mursel Ozdogan ${ }^{1}$, Gamze Basbulbul Ozdemir $^{3}$ \\ ${ }^{1}$ Adnan Menderes University Faculty of Agriculture, Department of Feed and Animal Nutrition, \\ South Campus, Aydın, Turkey \\ ${ }^{2}$ Adnan Menderes University Koçarlı Vocational School, South Campus, Aydın, Turkey \\ ${ }^{3}$ Adnan Menderes University Arts\&Science Faculty, Department of Biology, Kepez, Aydın, Turkey \\ austundag@adu.edu.tr
}

\begin{abstract}
This study evaluated the effects on the bacterial microflora in the cecum of Japanese quail caused by the addition of crude glycerol to their diet at different age. In this experiment, 480-day-old Japanese quails were used. Quails were assigned randomly into four dietary groups. The diets containing no glycerol (control diet) and $5 \%$ glycerol were used in the experiment. The first group (Group I) was fed with the control diet. Group II between 1-35-day-old, quails group III between 1-21-day-old, quails and group IV between 21-35-day-old quails were fed with the diet containing 5\% glycerol. At the same time, Group III and Group IV consumed control diet at the age of 22-35-days and 120-days, respectively. The experiment lasted 35 days. Cecum samples were collected from a total of 128 quails (16 female and 16 male in each group) at the age of 21- and 35-days. The amount of enterobacteria, coliform, and total bacteria was determined in the cecum. The groups of enterobacteria and coliform bacteria in the cecum of 21-day-old females and 35-day-old male quails only showed statistical difference among the groups. On the other hand, it was seen that the numbers of total bacteria of male $(\mathrm{P}<0.01)$ and female $(\mathrm{P}<0.05)$ quails at the age of 1 to 35 days fed with diet containing $5 \%$ glycerol between 21 and 35 days were significant in comparison to the control group of 35 days-old quails.
\end{abstract}

Key words: glycerol; quail; bacterial microflora; cecum

\section{ВЛИЈАНИЕ НА ДОДАВАЊЕТО ГЛИЦЕРОЛ ВО ИСХРАНАТА НА ЈАПОНСКИ ПОТПОЛОШКИ НА РАЗЛИЧНА ВОЗРАСТ ВРЗ МИКРОФЛОРАТА НА ЦЕКУМОТ}

\begin{abstract}
Ова истражување го оценува ефектот врз бактериската микрофлора во цекумот кај јапонски потполошки, предизвикан од додавање суров глицерол во нивната исхрана при различна возраст. Во овој опит беа користени јапонски потполошки стари 480 дена. Потполошките беа поделени во 4 групи. Во експериментот беше користена храна која не содржеше глицерол (контролна храна) и храна која содржеше 5\% глицерол. Првата група потполошки (група I) беше хранета со контролната храна. Групата II, составена од 1 до 35 дена стари потполошки, Групата III, составена од 1 до 21 ден стари потполошки и групата IV, составена од 21 до 35 дена стари потполошки, беа хранети со храна која содржи 5\% глицерол. Во исто време на групата III на возраст од 22 до 35 дена и на групата IV од 1 до 20 дена им беше давана контролната храна. Експериментот траеше 35 дена. Примероците од цекумот беа собрани од вкупно 128 потполошки (16 женки и 16 мажјаци во секоја група) на возраст од 21 и 35 дена. Во цекумот беше одредувана застапеноста на ентеробактериите, колиформните бактерии и вкупниот број на бактерии. Застапеноста на ентеробактериите и колиформните бактерии покажа статистички значајна разлика само помеѓу две групи потполошки, и тоа групата составена од женки на возраст од 21 ден и групата составена од мажјаци на возраст од 35 дена. Од друга страна пак беше забележана сигнификантност на застапеноста на вкупниот број бактерии кај машките $(\mathrm{P}<0,01)$ и кај женските $(\mathrm{P}<0,05)$ единки на возраст од 1 до 35 дена, кои беа хранети со храна која содржи 5\% глицерол, во однос на контролната група на возраст од 35 дена.
\end{abstract}

Клучни зборови: глицерол; потполошки; бактериска микрофлора; цекум 


\section{INTRODUCTION}

The gastrointestinal tract (GIT) of poultry, a complex ecosystem, is inhabited by a diverse and highly evolved community which comprises several hundred species of bacteria (Smulikowska, 2006). Although the alimentary tract of the newly hatched chick is usually sterile, organisms rapidly gain access from the mother and environment. The age of host animal is a major factor for microorganism development in guts. The number of microorganisms and their specificity to digestive tract segments in the young birds increase rapidly with the age in normal condition (Knarreborg et al., 2002; Van der Wielen et al., 2002; Zhu et al., 2002; Chambers and Gong, 2011). The diversity of bacterial species in the guts is one of the most important factors for the establishment of a stable ecosystem in the intestinal tract. A stable flora is essential for an animal to resist infections in the guts, optimal growth and performance (Torok et al., 2007; Choct, 2009). If the balance of microbial ecosytem is impaired, unfavourable microbiota may promote enteric infections, leading to decreeased growth rates and increased mortality. However, guts bacteria need not be pathogenic to impact negatively on the bird performance and production (Rehman, 2007; Torok et al., 2009). The knowledge of bacterial composition and activity as well as understanding the role of indigenous bacteria is important for development of feeding strategies that are aimed to change the intestinal bacterial communities (Rehman, 2007), because dietary factors (composition, digestibility, processing etc.) may disturb the microbial balance in the guts, especially in young animals. (Choct et al., 1996; Apajahalti et al., 2004; Choct, 2009).

Results of many studies have been documented compounds with glycerol such as monocaprin which caused a reduction in the number of microorganisms (Petschow et al., 1996; Thormar and Bergsson, 2001, Bergsson et al., 2001, 2002; Hilmarsson et al., 2006; Thormar et al., 2006). However, there are various studies showing glycerol is assessed by microorganisms. Da Silva et al. (2009) explained that glycerol was employed for the production of 1,3-propanediol, dihydroxyacetone, succinic acid, propionic acid, ethanol, citric acid, pigments, polyhydroxyalkanoates, and biosurfactants in industrial microbiology. Although there were many studies related to the effect of glycerol on microorganisms or poultry nutrition, studies demonstrating relationship between dietary glycerol and the number of cecal microorganism were not found.

The aim of this study was to determine the effects of crude glycerol fed at different age on cecal microorganism population of Japanese quails.

\section{MATERIAL AND METHODS}

Experimental procedures were approved by the Institutional Animal Care and Use Committee of Adnan Menderes University.

\section{Animals and diets}

A total of 480 one-day-old Japanese quail (Coturnix coturnix japonica) chicks was weighed and equally placed in sixteen cages (30 birds/cage). Cages were randomly divided into four groups of 120 chicks each. Each group was assigned to 4 replicates of 30 chicks each $(4 \times 4 \times 30)$. The experiment lasted for 35 days. The diets containing no glycerol and 5\% glycerol were used in the experiment. Group I was fed the diet containing no glycerol. Group II from 1 to $35 \mathrm{~d}$ of age, Group III from 1 to $21 \mathrm{~d}$ of age, and Group IV from 21 to 35 $\mathrm{d}$ of age were fed the diet containing $5 \%$ glycerol. At the same time, Group III and Group IV from 22 to 35-day of age and from 1 to 20-day of age, respectively consumed the control diet. The diets were formulated to meet requirements of quails according to the NRC (1994) in Table 1.

The quails were given access to the feed and water ad libitum during the experimental period. The chemical composition of the diets was determined based on the methods of the Association of Official Analytical Chemists (AOAC, 1997).

\section{Collection of cecal contents and microorganism analysis}

On deys $21^{\text {st }}$ and $35^{\text {th }}, 4$ birds $(2$ male +2 female) were slaughtered from each replication (a total of 128 birds / 21 and 35 deys of age) and immediately eviscerated for analysis. The contents of the cecum were immediately collected into sterile glass tubes and subjected to microbial analyses. Cecal contents of each bird were serially diluted 1:9 in buffered phosphate diluent and $100 \mu \mathrm{l}$ of each dilution was plated on PCA (Plate Count Agar), EMB agar and Levine Agar for enumeration of total microorganisms, coliform bacteria and enterobacteria. The plates were incubated $48 \mathrm{~h}$ at $37{ }^{\circ} \mathrm{C}$. The direct counts were converted to $\log _{10}$ colony forming unit per gram of cecal contents. 


\section{Statistical analysis}

Microorganism data did not show normal distribution, so they were transformed based on $\log 10$. All data were statistically analyzed using the GLM procedure with SAS 8 software. The differences among the means were tested using Duncan's multiple range tests. All statements of significance were based on a probability of $\mathrm{P}<0.05$.

Table 1

\section{Ingredients and nutrient composition of experimental diets, $\%$}

\begin{tabular}{lcc}
\hline Ingredient, \% & Control & Glycerol \\
\hline Corn & 42.8 & 37 \\
Wheat & 5 & 5 \\
Wheat bran & 5 & 5 \\
Soybean meal, 44\% CP & 38 & 38.6 \\
Fish meal, 65\% CP & 3.8 & 4 \\
Sunflower oil & 3.58 & 3.58 \\
DCP & 0.3 & 0.3 \\
Limestone & 0.8 & 0,8 \\
DL-Methionine & 0.12 & 0.12 \\
Glycerol & 0 & 5 \\
Salt & 0.25 & 0.25 \\
Vit. Min. Mix ${ }^{1}$ & 0.25 & 0.25 \\
Coccidiostat & 0.1 & 0.1 \\
\hline Chemical composition, \% & & \\
Crude protein & 26.00 & 25.81 \\
Ether extract & 5.99 & 5.64 \\
Metabolizable Energy, kcal /kg & 2908.1 & 2912.9 \\
\hline Suplying per kilg
\end{tabular}

${ }^{1}$ Supplying per kilogram of diet: Vit A 12000 IU, Vit D3 1500 IU, Vit E $30 \mathrm{mg}$, Vit K3 $5 \mathrm{mg}$, Vit B1 $3 \mathrm{mg}$, Vit B2 $6 \mathrm{mg}$, Vit B6 $5 \mathrm{mg}$, Vit B12 $0.03 \mathrm{mg}$, folic acid $0.75 \mathrm{mg}$, Ca D-pantotenat $10 \mathrm{mg}$, DBiotin $0.075 \mathrm{mg}$, cholin chloride $375 \mathrm{mg}$, nicotinamide $40 \mathrm{mg}, \mathrm{Mg} 80$ $\mathrm{mg}$, Fe $40 \mathrm{mg}$, Zn $60 \mathrm{mg}$, Cu $5 \mathrm{mg}$, I $0.4 \mathrm{mg}$, Co $0.1 \mathrm{mg}$, Se $0.3 \mathrm{mg}$ and antioxidant $10 \mathrm{mg}$

\section{RESULTS}

Effects of glycerol fed at different ages on cecal microorganism count of quails were given in tables.

There were no statistical differences on enterobacteria, coliform bacteria, and total microorganism count of male quails on 21 deys (Tables 2 , 3 , and 4).
Table 2

\section{Concentration of Enterobacteria in the cecum} of Japanese quails ${ }^{1}$

\begin{tabular}{lcccc}
\hline \hline & \multicolumn{2}{c}{21 day old quails } & \multicolumn{2}{c}{35 day old quails } \\
\cline { 2 - 5 } Groups & Male & Female & Male & Female \\
\hline Group I & 1.44 & $1.42^{\mathrm{ac}}$ & $0.69^{\mathrm{b}}$ & 1.02 \\
Group II & 2.22 & $2.31^{\mathrm{a}}$ & $1.84^{\mathrm{a}}$ & 1.66 \\
Group III & 1.82 & $1.87^{\mathrm{ab}}$ & $1.96^{\mathrm{a}}$ & 1.65 \\
Group IV & 2.13 & $0.82^{\mathrm{c}}$ & $0.60^{\mathrm{b}}$ & 1.19 \\
SEM & 0.17 & 0.18 & 0.17 & 0.13 \\
$\mathrm{P}$ & 0.36 & 0.02 & 0.001 & 0.23 \\
\hline \hline
\end{tabular}

Group I: Control, Group II: Diet with glycerol between 1 and 35 d, Group III: Diet with glycerol between 1 and 21 d, Group IV: Diet with glycerol between 21 and $35 \mathrm{~d}$.

${ }^{1} \log 10 \mathrm{cfu} / \mathrm{ml}$.

${ }^{a, b, c}$ Means with the same superscript in the line are not significantly different.

Enterobacteria $(\mathrm{P}<0.05)$ and coliform bacteria $(\mathrm{P}<0.01)$ counts of female quails were statistically different on $21 \mathrm{~d}$ (Tables 2 and 3). There was no statistical difference on the total microorganism count in the groups (Table 4). While minimum enterobacteria and coliform bacteria counts in the cecum were seen in Goup IV, maximum enterobacteria and coliform bacteria counts were seen in Group II.

Table 3

\section{Concentration of Coliform bacteria in the cecum} of Japanese quails ${ }^{1}$

\begin{tabular}{lcccc}
\hline \hline & \multicolumn{2}{c}{ 21 day old quails } & \multicolumn{2}{c}{35 day old quails } \\
\cline { 2 - 5 } Groups & Male & Female & Male & Female \\
\hline Group I & 1.42 & $1.38^{\mathrm{bc}}$ & $0.78^{\mathrm{b}}$ & 1.20 \\
Group II & 2.24 & $2.34^{\mathrm{a}}$ & $1.87^{\mathrm{a}}$ & 1.75 \\
Group III & 1.87 & $1.90^{\mathrm{ab}}$ & $1.86^{\mathrm{a}}$ & 1.65 \\
Group IV & 2.07 & $0.77^{\mathrm{c}}$ & $0.49^{\mathrm{c}}$ & 1.33 \\
SEM & 0.16 & 0.19 & 0.17 & 0.14 \\
$\mathrm{P}$ & 0.31 & 0.01 & 0.001 & 0.47 \\
\hline \hline
\end{tabular}

Group I: Control, Group II: Diet with glycerol between 1 and 35 d, Group III: Diet with glycerol between 1 and 21 d, Group IV: Diet with glycerol between 21 and $35 \mathrm{~d}$.

${ }^{1} \log 10 \mathrm{cfu} / \mathrm{ml}$.

${ }^{a, b, c}$ Means with the same superscript in the line are not significantly different. 
On $35 \mathrm{~d}$, enterobacteria and coliform bacteria in the cecum of male birds were significantly important between the groups $(\mathrm{P}<0.01)$. While minimum enterobacteria counts were observed in Group IV and Group I, maximum enterobacteria counts were observed in Group II and Group III. On the other hand, minimum of coliform bacteria counts were seen in Group IV, maximum enterobacteria counts were seen in Group II and Group III.

Table 4

Concentration of total bacteria in the cecum of Japanese quails ${ }^{1}$

\begin{tabular}{lcccc}
\hline \hline & \multicolumn{2}{c}{ 21 day old quails } & \multicolumn{2}{c}{35 day old quails } \\
\cline { 2 - 5 } Groups & Male & Female & Male & Female \\
\hline Group I & 1.50 & 1.50 & $1.37^{\mathrm{b}}$ & $1.57^{\mathrm{b}}$ \\
Group II & 2.45 & 2.55 & $2.24^{\mathrm{a}}$ & $2.41^{\mathrm{a}}$ \\
Group III & 2.07 & 2.65 & $1.87^{\mathrm{ab}}$ & $2.03^{\mathrm{ab}}$ \\
Group IV & 2.05 & 1.44 & $1.52^{\mathrm{b}}$ & $1.94^{\mathrm{ab}}$ \\
SEM & 0.17 & 0.22 & 0.10 & 0.11 \\
P & 0.28 & 0.07 & 0.006 & 0.03 \\
\hline \hline
\end{tabular}

Group I: Control, Group II: Diet with glycerol between 1 and $35 \mathrm{~d}$, Group III: Diet with glycerol between 1 and 21 d, Group IV: Diet with glycerol between 21 and $35 \mathrm{~d}$.

${ }^{1} \log 10 \mathrm{cfu} / \mathrm{ml}$

a,b,c Means with the same superscript in the line are not significantly different.

Total bacteria counts were significant by different among groups in male $(\mathrm{P}<0.01)$ and female $(\mathrm{P}<0.05)$ on $35 \mathrm{~d}$. Minimum and maximum total bacteria counts were observed in Group I and Group II in both sexes, respectively.

\section{DISCUSSION}

Dietary factors may disturb the microbial balance in the guts, especially in young animals. (Choct et al., 1996; Apajahalti et al., 2004; Choct, 2009). So, the knowledge of bacterial composition and activity as well as understanding the role of indigenous bacteria can be important for development of feeding strategies that are aimed to change the intestinal bacterial communities (Rehman, 2007). In the present study, when analysing the effects of glycerol on the number of cecal entero- bacteria, coliform bacteria and total microorganism at different ages of quail fed with 5\% glycerol, minimum enterobacteria and coliform bacteria counts of female at $21 \mathrm{~d}$ of age and male birds at $35 \mathrm{~d}$ of age were observed in Group IV. It was considered that microbial activity, the enterobacteria, coliform bacteria and total bacteria especially at male and female usually increased by diet with $5 \%$ glycerol fed between 1 and $35 \mathrm{~d}$ of age and 1 and $21 \mathrm{~d}$ of age. It was stated that there was a positive relation between glycerol and microorganisms in microbiology and biotechnology researches (Da Silva et al., 2009; Hilmarsson et al., 2006; Takeshi et al., 2005; Remize et al., 1999). However, there are various studies showing glycerol is assessed by microorganism. Glycerol is employed for the production of 1,3-propanediol, dihydroxyacetone, succinic acid, propionic acid, ethanol, citric acid, pigments, polyhydroxyalkanoates, and biosurfactants in industrial microbiology (Da Silva et al. 2009). On the other hands, it has been documented that compounds with glycerol such as monocaprin caused a reduction in the number of microorganisms (Petschow et al., 1996; Thormar and Bergsson, 2001, Bergsson et al., 2001, 2002; Hilmarsson et al., 2006; Thormar et al., 2006). But, previous studies demonstrating relationship between dietary glycerol and the number of cecal microorganism were not found.

There are not enough studies demonstrating relationship between amounts of dietary glycerol and the number of gut microorganisms in poultry at different ages. Therefore, more studies are needed on the effects of glycerol amounts in poultry intestinal.

\section{REFERENCES}

[1] AOAC (1997): Official methods of analysis. 16th ed. Association of official Analytical Chemists, Washington, D.C..

[2] Apajalahti, J., Kuttunen, A., Graham, H. (2004): Characteristics of the gastrointestinal microbial communities, with special reference to the chicken. World's Poultry Science Journal, 60, 223-232.

[3] Bergsson, G., Arnfinnsson, J., Steingrímsson, Ó., Thormar, H. (2001): Killing of gram-positive cocci by fatty acids and monoglycerides. APMIS, 109, 670-678.

[4] Bergsson, G., Steingrímsson, Ó., Thormar, H. (2002): Bactericidal effects of fatty acids and monoglycerides on Helicobacter pylori., Int. J. Antimicrob. Agents, 20, 258262. 
[5] Chambers, J. R., Gong, J. (2011): The intestinal microbiota and its modulation for Salmonella control in chickens. Food Research International, 44, 3149-3159.

[6] Choct, M. (2009): Managing gut health through nutrition. British Poultry Science, 50 (1), 9-15.

[7] Choct, M., Hughes, R. J., Wang, J., Bedford, M. R., Morgan, A. J., Annison, G. (1996): Increased small intestinal fermentation is partly responsible for the antinutritive activity of non-starch polysaccharides in chickens. British Poultry Science, 37, 609-621.

[8] Da Silva, G. P., Mack, M., Contiero., J. (2009): Glycerol: A promising and abundant carbon source for industrial microbiology. Biotech. Adv., 27, 30-39.

[9] Hilmarsson, H., Thormar, H., Thráinsson, J. H., Gunnarsson, E. (2006): Effect of glycerol monocaprate (Monocaprin) on broiler chickens: an attempt at reducing intestinal Campylobacter infection. Poultry Science, 85, 588592.

10] Knarreborg, A., Simon, M. A., Engberg, R. M., Jensen, B. B., Tannock G. W. (2002): Effects of dietary fat source and subtherapeutic levels of antibiotic on the bacterial community in the ileum of broiler chickens at various ages. Appl. Environ. Microbiol., 68, 5918-5924.

[11] NRC (1994): Nutrient requirements of poultry, 9. revised edition. National Research Council. National Acedemy Press, Washington, D. C.

[12] Petschow, B. W., Batema, R. P., Ford, L. L. (1996): Susceptibility of Helicobacter pylori to bactericidal properties of medium-chain monoglycerides and free fatty acids. Antimicrobial Agents and Chemotherapy, 40 (2), 302306.

[13] Rehman, H. U., Vahjen, W., Awad, W. A., Zentek, J. (2007): Indigenous bacteria and bacterial metabolic products in the gastrointestinal tract of broiler chickens. Archives of Animal Nutrition, 61 (5), 319-335.

[14] Remize, F., Roustan, J. L., Sablayrolles, J. M., Barre, P., Dequin, S. (1999): Glycerol Overproduction by Engineered Saccharomyces cerevisiae Wine Yeast Strains Leads to Substantial Changes in By-Product Formation and to a
Stimulation of Fermentation Rate in Stationary Phase. Appl. Environ. Microbiol., 65 (1), 143-149.

[15] SAS (1999): The SAS System SAS Institute Inc., Cary, NC, USA, Version 8 Copyright (C) 1999.

[16] Smulikowska S. (2006): Manipulation of the Poultry Ecosystem through Biotechonology. In: Mosenthin R, Zentek J, Zebrowska T. (editors). Biology of nutrition in growing animals. Vol. 4. London: Elsevier. pp 597 609.

[17] Takeshi, I., Nakashimada, Y., Senba, K., Matsui, T., Nishio, N. (2005): Hydrogen and ethanol production from glycerol-containing wastes discharged after biodiesel manufacturing process. J. Biosci Bioeng., 100 (3), 260265 (2005)

[18] Thormar, H., Bergsson, G. (2001): Antimicrobial effects of lipids. Recent Dev. Antiviral Res., 1, 157-173.

[19] Thormar, H., Hilmarsson, H., Bergsson, G. (2006): Stable concentrated emulsions of the 1-monoglyceride of capric acid (Monocaprin) with microbicidal activities against the food-borne bacteria Campylobacter jejuni, Salmonella spp., and Escherichia coli. Appl. Environ. Microbiol., 72 (1), 522-526.

[20] Torok, V. A., Ophel-Keller, K., Hudges, R. J., Forder, R., Ali, M., Macalpine, R. (2007): Environment and age: impact on poultry gut microflora. Aust. Poult. Sci. Symp., pp. 149-152.

[21] Torok, V. A., Allison, G. E., Ophel-Keller, K., Hughes, R. J. (2009): The post-hatch gut microbiota development in broiler chickens. Aust. Poult. Sci. Symp., pp. 73-80.

[22] Van der Wielen, P. W. J. J., Keuzenkamp, D. A., Lipman, L. J. A., van Knapen, F., Biesterveld, S. (2002): Spatial and temporal variation of the intestinal bacterial community in commercially raised broiler chickens during growth. Microb Ecol., 44, 286-293.

[23] Zhu, X. Y., Zhong, T., Pandya, Y., Joerger. R. D. (2002): $16 \mathrm{~S}$ rRNA-based analysis of microbiota from the cecum of broiler chickens. Appl. Environ. Microbiol., 68, 124137. 